\title{
The Effect Pineaple Rind Extract (Ananas comosus L.) (Merr var. cayenne) Attack Intensity Cauliflower's Pests (Brassica oleracea var. botrytis L. subvar. Cauliflora DC.)
}

\author{
Sonja Lumowa ${ }^{1}$, Sri Purwati ${ }^{1} \&$ Syamsuryanto ${ }^{1}$ \\ ${ }^{1}$ University of Mulawarman Indonesia, Indonesia \\ Correspondence: Sonya Lumowa, University of Mulawarman Indonesia, Indonesia. E-mail: verasonja@yahoo.com
}

Received: March 15, 2018

Accepted: March 25, 2018

Online Published: April 10, 2018

doi:10.5539/ijb.v10n3p1

URL: https://doi.org/10.5539/ijb.v10n3p1

\begin{abstract}
The effect of pineaple rind extract (Ananas comosus (L.) Merr var. Cayenne) towards the intensity of pests attack from cauliflower (Brassica oleracea var. botrytis L. subvar. cauliflora DC.). The purpose of this research is to find out the effect of pineaple rind extract (Ananas comosus (L.) Merr var. Cayenne) towards the intensity of pests attack from cauliflower (Brassica oleracea var. botrytis L. subvar. cauliflora DC.). This research has been held for 2 months. The field reseach was held in the field in Loa Ipuh Laut Kecamatan Tenggarong Kota. This research used Random group design (RAK) with five treatments (control included) that has been repeated for twenty five times. Every treatment was $25 \%, 50 \%, 75 \%$ and the control (without treatment) then was analyzed by using Anaysis of Variance (ANOVA) and was continued with BNJ test $5 \%$. The result of the research showed that every value was $\mathrm{F}_{\text {arithmetic }}(46,79)(212,3)(66,14)(194,96)(82,11)>\mathrm{F}_{\text {table }}(3,01)$ it can be concluded that the allotment of vegetal pesticide from pineaple rind (Ananas comosus (L.) Merr var. Cayenne) can decrease the intensity of pests attack from cauliflower (Brassica oleracea var. botrytis L. subvar. cauliflora DC.).
\end{abstract}

Keywords: Pineaple rind extract, attack intensity, caulifwer's pets

\section{Introduction}

Pineaple (Ananas comosus (L..) Merr) is one of the kind of fruits in Indonesia. Indonesian people is familiar with pineaple, because it has been consumed as a fresh fruit. Pineaple usually can be processed to be fresh drink like pineaple juice or syrup. The research done by (Budiman \& Destina, 2014) Pineaple (Ananas comosus (L..) Merr) Varietas Cayenne can decrease high blood pressure, this is because pineaple consists of Vitamin C.

In a place where the researcher lives, Tenggarong city, the researcher often sees pineaple rind cayenne variety is piled up at the traditional market and is thrown away offhanded. The waste of this pineaple rind is organic waste that still has a lot of nutrition that can be used. But this pineaple organic waste that consists of high water content is easy to become septic. If it is left just like that without handling it, it will contaminate the environment. The pineaple rind that usually goes to waste, if it is used right, it will become a new innovation that the environment will not be contaminated by that pineaple rind.

The pineaple rind that has been thrown away as a waste, consists of Vitamin C, karotenoid and flavonoid (Erukainure et al., 2011). Based on the research done by it can be known that the pineaple rind extract with maceration method contains $3,51 \mu \mathrm{g} / \mathrm{mL}$ of flavonoid. The content of other active compounds in pineaple rind are saponin, tanin, and flavonoid that can be used to control pests in plants through extraction process. According to (Audie, 2015) extract is the collection of some compounds from various groups that dissolved in the suitable solution, including active and inactive compounds in it.

The pineaple rind extract can also be used as the substance to control pests. According to (Cahyono, 2001) pest is a destructor that attacks crops, plants, root, stem, leaf, or any other parts of plan that makes the plan itself not able to perfectly grow or die. Pest can also undermine horticulture plants. One of the cultivated plants in Indonesia is from vegetable, in this case, cauliflower. A lot of farmers in Kutai Kartanegara where the researcher lives think that the pests from cauliflower are too many that the formers are not willing to plant it. Actually it is not like that, if we observe it everyday and the prevention is done, then the attact from the pests would not be so hard and useless (Hatam at al., 2013).

Most pests that attack cauliflower are caterpillars and flea. And then to resolve the attack, the farmers usually use chemical pesticide. But if the pesticide is overly used, it will give bad effect for health. To control those pests, it is better to use the kind of pesticide that is unraveled easily such as vegetal pesticide. According to (Kardinan, 2002) 
vegetal pesticide is a pesticide which the active substance is from plant and other organic substances that will be useful to control the pest attack. On that basis, the researcher wants to use the extract of pineaple rind (Ananas comosus (L.) Merr var. cayenne) that contains active compounds such as alkaloid, flavonoid, tannin and saponin to mantain pests in cauliflower (Brassica oleracea var. botrytis L. subvar. Cauliflora DC.) (Cauliyah, 2015).

\section{Method}

The type of this method is True Eksperimental Research that is purposed to know and to find the possibility of cause and effect by real designing of group treatment and control treatment and comparing the treatment result with the control group that is not getting any treatment. (Nurboko, 2014). The design used is random group design, because the research location was done in a field that consists of 5 treatments (including control) dan eachof them has been repeated 5 times as a group. This research used random group design as the simplest design that is suitable for field experiment (Murdiyanto, 2005).

The research location is in Tenggarong district in East Kalimantan, with 30 degree celcius of stable weather condition, and the field used is farming group field in that village and using 5 embankments consist of cucumber plant. The research was started from seeding process which put the seeds of cauliflower in a place that had been prepared and had been watered first, so the land for seedbed becomes humid. The field that had been spreaded with seeds then was closed by using sack to keep the humidity from the soil that can help speeding up the growth of shoot from seed of cauliflower (Cahyono, 2001).

The seeding had been done for 21 days until cauliflower candidate ready or amounted at least 5 to 6 leaves to be moved to the research field. Vegetal pesticide was made by processing pineaple rind from preparing each of 500 grams of pineaple rinds then each of that was blended with $1500 \mathrm{ml}$ of water. In making this vegetal pesticide, the used solvent was water, this is to make the content of chemical content that can cause negative effect in applying it on plants. The spraying or applying pineaple rind extract was started when the plant age was 14 days after the cultivation in the dewfall. The pineaple rind extract was applied once every three days to increase the effectivity of that extract in decriesing the intensity of pests attack that often attack cauliflower. Because, the shortcoming of vegetal pesticide is quickly decomposed and the application has to be often, low toxicity level, cannot directly kill pests/has slow effect (Kardinan, 2002; Rizky Dwidyanti \& Ika Andriani, 2013).

The tools and materials used in this research are blender, basin, mulch, sack, mattock, weigher, hand-sprayer, strainer, measuring cup, rope, gauge, camera, stationary, cauliflower seeds (Brassica oleracea var.botrytis L.subvar.Cauliflora DC.), 500 grams of pineaple rind (Ananas comosus (l.) Merr var. cayenne), 2 grams of detergent, water, and manure. This research procedure was started from seeding, planting the cauliflower at the age of 21 days, nurturing by watering and cleaning the weeds, applying pineaple rind extract in a different treatment which is $25 \%, 50 \%, 75 \%$ extract and controlled treatment and harvesting. The application of pineaple skin by using handspray that is sprayed to cucumber leaves for trial, each embarkment will get different concentration extract based on the calculation of the concentration above. The technic for data collection was done once every week until it reached 5 weeks. Calculating the intensity of pests that attack the leaf are from 21 and 28 days after the plant was compared by using this formula:

$$
I=\frac{\Sigma \text { daun yang diserag hama }}{\Sigma \text { daun yang diamati }} \times 100 \%
$$

Explanation: $\mathrm{I}=$ the attack intensity (\%) With 0 as the scale value (means that there was not any attack from pests/the plant was healthy), 1 (the damage is under $25 \%$ venial pests attack), 2 (the damage is $25-50 \%$ (medium pests attack), 3 (the damage is $50-75 \%$ (severe pest attack), 4 (the damage is more than $75 \%$ means that the attack is very serious) (Leatemia, 2011). Then the collecting data was analyzed by using analysis of variance - group random design with analysis of variance (ANOVA) with $95 \%$ of confidence interval. And continued by $5 \%$ of BNJ. How to calculate it is as follows:

$$
\begin{gathered}
F K=\frac{T_{i j^{2}}}{k x t} \\
J K T=T\left(Y^{2}{ }_{i j}\right)-\mathrm{FK} \\
J K K=\frac{T K^{2}{ }_{i}}{t}-F K \\
J K P=\frac{T P^{2}}{K}-F K \\
\mathrm{JKG}=\mathrm{JKT}-\mathrm{JKK}-\mathrm{JKP}
\end{gathered}
$$




\section{Results}

The intensity of pests attack in cauliflower (Brassica oleracea var. botrytis L. subvar. Cauliflora DC.).

Table 1 . The intensity of pests attack on the 21 st day after cultivation

\begin{tabular}{cccccccc}
\hline \multirow{2}{*}{ Treatment } & \multicolumn{3}{c}{ Repetition } & \multicolumn{2}{c}{ Total } & Average \\
\cline { 2 - 8 } & $\mathrm{R}_{1}$ & $\mathrm{R}_{2}$ & $\mathrm{R}_{3}$ & $\mathrm{R}_{4}$ & $\mathrm{R}_{5}$ & $\mathrm{TP}_{\mathrm{j}}$ & $\overline{\mathrm{y}} \mathrm{P}_{\mathrm{j}}$ \\
\hline $\mathrm{P}_{0}$ & 72.67 & 74.48 & 73.90 & 77.26 & 65.62 & 363.93 & 72.79 \\
$\mathrm{P}_{1}$ & 61.71 & 71.67 & 66.67 & 66.12 & 53.43 & 319.60 & 63.92 \\
$\mathrm{P}_{2}$ & 59.57 & 52.83 & 35.29 & 46.40 & 30.90 & 225.00 & 45.00 \\
$\mathrm{P}_{3}$ & 46.07 & 48.69 & 38.36 & 35.26 & 31.86 & 200.24 & 40.05 \\
$\mathrm{P}_{4}$ & 39.24 & 30.57 & 36.10 & 27.81 & 27.02 & 160.74 & 32.15 \\
Total $\left(\mathrm{TR}_{\mathrm{i}}\right)$ & 279.26 & 278.24 & 250.31 & 252.86 & 208.83 & 1269.50 & 253.90 \\
\hline Sounyyyyyyy
\end{tabular}

Source : Research result (2016)

Information

$\mathrm{Po}=$ Control group

$\mathrm{P} 1=$ Treatment Konsentrasi 25\%

$\mathrm{P} 2=$ Treatment Konsentrasi $25-50 \%$
$\mathrm{P} 3=$ Treatment konsentrasi $50-75 \%$

$\mathrm{P} 4=$ Treatmen konsentrasi $75 \%$

Table 2. Analysis result of variance on the 21st day after cultivation

\begin{tabular}{cccccc}
\hline \multirow{2}{*}{ The source of variety } & $\begin{array}{c}\text { Degree of freedom } \\
\text { (DF) }\end{array}$ & $\begin{array}{c}\text { Total squares } \\
\text { (TS) }\end{array}$ & $\begin{array}{c}\text { Median squares } \\
\text { (MS) }\end{array}$ & F count & F Tabel (5\%) \\
\hline Group & 4 & 656.11 & 164.03 & 5.33 & $4,16=3.01$ \\
Treatment & 4 & 5763.22 & 1440.81 & 46.79 & $4,16=3.01$ \\
Galat & 16 & 492.69 & 30.79 & & \\
Total & 24 & 6912.02 & & & \\
\hline
\end{tabular}

Explanation: variety coefficient $=2,2$ (source : research result, 2016).

From the total of F-count (46.79) > F-tabel (3.01) that makes pineaple rind extract succeed to decrease the intensity of pests attack. Based on that data analysis, it can be inferred that pineapple skin extract has a big impact to decrease the intensity of pest attacking cucumber plant.

Table 3. Continued test BNJ level $5 \%$ age 21 days after cultivation

\begin{tabular}{ccccccc}
\hline \multirow{2}{*}{ Treatment } & Average (\%) & \multicolumn{5}{c}{ Median } \\
\cline { 3 - 7 } & & 72.79 & 63.92 & 45 & 40.05 & 32.15 \\
\hline P0 & 72.79 & 0 & 8.87 & $27.79^{*}$ & $32.74^{*}$ & $40.64^{*}$ \\
P1 & 63.92 & -8.87 & 0 & $18.92^{*}$ & $23.87^{*}$ & $31.77^{*}$ \\
P2 & 45 & -27.79 & -18.92 & 0 & 4.95 & $12.85^{*}$ \\
P3 & 40.05 & -32.74 & -23.87 & -4.95 & 0 & 7.9 \\
P4 & 32.15 & -40.64 & -31.77 & -12.85 & -7.9 & 0 \\
\hline
\end{tabular}

Explanation: *: real different ( deviation $>$ BNJ test) (Source: research result, 2016).

Based on BNT test above it can be seen that the level of failure from this research is minimum, that the application of pineapple skin extract to decrease the growth of pest intensity is real. For control group, it can be seen that the pest is growing fast while the treatment group shows that there is a reduction of pest and specifically in $\mathrm{P} 4$, the pest is none. 
Table 4 . The intensity of pest attack at the age of 28 days after cultivation

\begin{tabular}{cccccccc}
\hline \multirow{2}{*}{ treatment } & \multicolumn{3}{c}{ repetition } & \multicolumn{2}{c}{ Total } & \multicolumn{2}{c}{ Average } \\
\cline { 2 - 8 } & $\mathrm{R}_{1}$ & $\mathrm{R}_{2}$ & $\mathrm{R}_{3}$ & $\mathrm{R}_{4}$ & $\mathrm{R}_{5}$ & $\mathrm{TP}_{\mathrm{j}}$ & $\overline{\mathrm{y}} \mathrm{P}_{\mathrm{j}}$ \\
\hline $\mathrm{P}_{0}$ & 83.81 & 78.77 & 83.57 & 85.48 & 77.29 & 408.92 & 81.78 \\
$\mathrm{P}_{1}$ & 73.33 & 63.57 & 63.33 & 62.46 & 58.67 & 321.36 & 64.27 \\
$\mathrm{P}_{2}$ & 42.26 & 42.03 & 44.51 & 46.98 & 37.50 & 213.28 & 42.66 \\
$\mathrm{P}_{3}$ & 34.45 & 39.11 & 29.93 & 31.05 & 29.94 & 164.48 & 32.90 \\
$\mathrm{P}_{4}$ & 30.02 & 21.11 & 28.78 & 21.75 & 23.38 & 125.04 & 25.01 \\
Total $\left(\mathrm{TR}_{\mathrm{i}}\right)$ & 263.87 & 244.59 & 250.12 & 247.72 & 226.78 & 1233.08 & 246.62 \\
\hline
\end{tabular}

Source : Research result (2016).

Information

Po $=$ Control group

$\mathrm{P} 3=$ Treatment konsentrasi $50-75 \%$

$\mathrm{P} 1=$ Treatment Konsentrasi $25 \%$

P4= Treatmen konsentrasi 75\%

$\mathrm{P} 2=$ Treatment Konsentrasi $25-50 \%$

Table 5. The result of variance analysis at the age of 28 days after cultivation

\begin{tabular}{cccccc}
\hline Variance source & Degree of freedom $(\mathbf{D b})$ & Total squares $(\mathbf{J K})$ & Median squares $(\mathbf{K T})$ & F count & F Tabel (5\%) \\
\hline Group & 4 & 141.75 & 35.44 & 2.76 & $4,16=3.01$ \\
Treatment & 4 & 10913.52 & 2728.38 & 212.30 & $4,16=3.01$ \\
Error & 16 & 205.62 & 12.85 & & \\
Total & 24 & 11260.89 & & \\
\hline
\end{tabular}

Explanation: Variance coefficient $=1,5$ (Source: research result, 2016).

From the result of Fcount (212.30) > Ftabel (3.01) that makes pineaple rind extract succeed to decrease the intensity of pests attack Based on that data analysis, it can be inferred that the pineapple skin has a big impact in reducing pest intensity that attack cucumber plant.

Tabel 6. Continued test BNJ level 5 age 28 days after cultivation

\begin{tabular}{ccccccc}
\hline \multirow{2}{*}{ Treatment } & Average (\%) & \multicolumn{5}{c}{ Median } \\
\cline { 3 - 7 } & & 81.78 & 64.27 & 42.66 & 32.9 & 25.01 \\
\hline P0 & 81.78 & 0 & $17.51^{*}$ & $39.12^{*}$ & $48.88^{*}$ & $56.77^{*}$ \\
P1 & 64.27 & -17.51 & 0 & $21.61^{*}$ & $31.37^{*}$ & $39.26^{*}$ \\
P2 & 42.66 & -39.12 & -21.61 & 0 & $9.76^{*}$ & $17.65^{*}$ \\
P3 & 32.90 & -48.88 & -31.37 & -9.76 & 0 & $7.89^{*}$ \\
P4 & 25.01 & -56.77 & -39.26 & -17.65 & -7.89 & 0 \\
\hline
\end{tabular}

Explanation: *: real difference ( deviation > BNJ test), (Source : result research, 2016).

Based on BNT test above it can be seen that the level of failure from this research is minimum, that the application of pineapple skin extract to decrease the growth of pest intensity is real. For control group, it can be seen that the pest is growing fast while the treatment group shows that there is a reduction of pest and specifically in $\mathrm{P} 4$, the pest is none.

Table 7. Insects Discovered During the Research

\begin{tabular}{ccc}
\hline NO & Species name & Total \\
\hline 1 & Plutella xylostella L. & 10 \\
2 & Atractomorpha crenulata & 27 \\
\hline
\end{tabular}

Source: research result (2016).

The pets found during the research were Plutella xylostella. $L$ and Atractomorpha crenulata where these two names are known to attack cucumber plantsthat specifies damaging the leaves of cucumber, that make the plants cannot grow bigger because it cannot do the photosynthesis perfectly. The application of using pineapple skin extract can be said as natural pesticides that reduce the growth og pets in plants because it is able to kill the pets that attact plants. 


\section{Discussion}

The result of the research that had beem done during the research, especially on the 21st, 28th, after cultivation showed that the intensity of pests attack in cauliflower that got high concentrate of pineaple rind extract sustained pests attack less than the cauliflower that got pineaple rind extract with low concentrate or control. According to variance analysis result, the intencity of pests attack at the age of 21 and 28,days after cultivation also showed that by giving vegetal pesticide from pineaple rind for cauliflower has real effect in decreasing the intensity of pests attack. Pada minggu pertama atau 21 hari It can be seen from Fcount $(46,7)$ that is higher than Ftable (3.01). Whereas in the secon week or 28 days it can be seen that from Fcount $(212,30)$ it is higher than Ftable (3.01).

According to the average of pests attack intensity in every age of cauliflower observation showed that vegetal pesticide from pineaple rind has almost the same average intensity of pest attack. According to the research that has been done by (Hatam, 2013) it can be known that pineaple rind extract with maceration extraction process contains, it can be known that pineapple skin extract with extraction method consists of $3,51 \mu \mathrm{g} / \mathrm{mL}$ flavonoid total that can decrease eating activity of pests and antifeedant. This is because pineaple rind contains flavonoid which is a defence compound that is inhibiting food from pests and toxis (substance that causes poisoning) (Dinata, 2009). How poison insecticides get inside pests body by natural holes from pests body. After it gets inside the pests whole body and attack their nervous system that will distract the pests activity and the pests will die.

According to the observation during the research and the calculation that had been done, it showed that there is a real effect from pineaple rind extract to the intensity of pests attack in cauliflower, (Siti Juariah at al., 2017). The research result showed that there is a very signifficant difference between pests attack to cauliflower that was given treatment by vegetal pesticide application from pineaple rind extract compared to cauliflower that was not getting vegetal pesticide from pineaple rind extract. This proves that secondary metabolite compound from pineaple rind indeed has potential as toxic substance for pests so it can be used as vegetal pesticide.

\section{Conclusion}

The use of vegetal pesticide from pineaple rind (Ananas comosus (l.) Merr var. cayenne) has the real effect to control the intensity of pests attack in cauliflower (Brassica oleracea var. botrytis L. subvar. Cauliflora DC.) with the most prominent treatment in $\mathrm{P}_{4}$ (pineaple rind extract with $75 \%$ concentrate).

\section{Suggestion}

To all farmers, they need to use vegetal pesticide from pineaple rind as the solution for alternative pesticide which is cheap and environmentally friendly. It is necessary to do further research regarding plants that have potency as vegetal pesticide to overcome the plat-disturbing organisms (OPT). It is expected that this reseach can enhance knowledge and insight for etymology subject in plant metabolite compound that can help biological control.

\section{Acknowledgments}

I thank The Directorate General of Research and Technology Research and Development, The Directorate of Research and Community Service of Research, Technology and Higher Education which have facilitated the research funding for 2 consecutive years. This year is the third year, funding the last year through ongoing grant fund contract research graduate research in 2017.

\section{References}

Annisa, A. (2015). Uji Efektivitas Antibakteri Ekstrak Kulit Nanas (Ananas comosus. L) TERHADAP PERTUMBUHAN Streptococcus Mutans PENYEBAB KARIES GIGI (Doctoral dissertation, UPT. Perpustakaan Unand).

Budiman, I., \& dan Destina, T. (2014). Pineaple effect (Ananas comosus (L..) Merr) towards the decrease of blood pressure. Christian Maranatha University.

Cahyono, B. (2001). Cabbage flower dan Broccoli. Kanisius: Yogyakarta.

Chauliyah, A. I. N., \& Murbawani, E. A. (2015). Analisis kandungan gizi dan aktivitas antioksidan es krim nanas madu (Doctoral dissertation, Diponegoro University).

Dinata, L. P. (2009). Herba Tapak Dara Tablet Extract formulation (Catharantus roseus (L) G. Don) with gelatin binder and Arabic Gom in Various Concentrate. Muhammadyah University of Surakarta. 
Erukainure, O. L., Ajiboye, J. A., Adejobi, R. O., Okafor, O. Y., \& Adenekan, S. O. (2011). Protective effect of pineapple (Ananas cosmosus) peel extract on alcohol-induced oxidative stress in brain tissues of male albino rats. Asian Pacific Journal of Tropical Disease, 1(1), 5-9. https://doi.org/10.1016/S2222-1808(11)60002-9

Hatam, S. F. (2013). Antioxidant Activity from pineaple rind extract (Ananas comosus (L) Merr). FMIPA UNSRAT: Manado

Kardinan, A. (2002). Herbs and Apps of Vegetal Pesticide. The fourth mold. Penebar Swadaya: Jakarta.

Leatemia, J. A. (2011). The study of damage caused by pests attack in crops in Bula district, Kabupaten Seram Bagian Timur, Propinsi Maluku. Agroforestri Journal Volume VI Nomor 1.

Murdiyanto, B. (2005). Experimental Design. Retrieved from http://ikanlaut.tripod.com/xdesign.pdf

Nurboko, A. (2014). Research methodology. Jakarta: PT Bumi Aksara.

Rizky Dwidyanti dan Ika Andriani. (2013). Daya Antibakteri Ekstrak Kulit Buah Nanas (Ananascomosus) terhadap pertumbuhan Bakteri Aggregatibacter actinomycetemcomitans. Fakultas Kedokteran. Universitas Andalas.

Siti Juariah dan Mega Pratiwi. (2017). UJPH (X) 20XX Biolarvasida ekstrak etanol kulit Nanas (Ananans Comous L, Merr) terhadap Larva Nyamuk Culex SP.

\section{Copyrights}

Copyright for this article is retained by the author(s), with first publication rights granted to the journal.

This is an open-access article distributed under the terms and conditions of the Creative Commons Attribution license (http://creativecommons.org/licenses/by/4.0/). 